\title{
Screening and Identifying a Cadmium-Resistant Fungus and Characterizing its Cadmium Adsorption
}

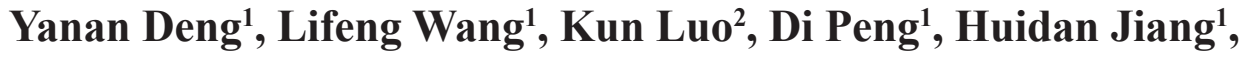 \\ Chenzhong $\mathrm{Jin}^{3}$, Xiaomao Zhou ${ }^{1 *}$, Lianyang Bai ${ }^{1 * *}$ \\ ${ }^{1}$ Hunan Agricultural Biotechnology Research Center, Changsha, 410125, Hunan, China \\ ${ }^{2}$ College of Plant Protection, Hunan Agricultural University, Changsha, 410125, Hunan, China \\ ${ }^{3}$ Collaborative Innovation Center for Field Weeds Control, Loudi, 417000, Hunan, China
}

Received: 21 October 2016

Accepted: 12 December 2016

\begin{abstract}
The main aim of this study was to screen and identify cadmium-resistant fungus and to characterize its cadmium adsorption. A cadmium-resistant strain (CN35) was isolated from cadmium-polluted paddy soil. Based on morphlogical characteristics, internal transcribed spacers region and $\beta$-tubulin gene sequence phylogenesis analysis, the strain was preliminarily identified to be Penicillium $\mathrm{sp}$. This strain was resistant to $\mathrm{Cd}$ at $45 \mathrm{mM}$ with $\mathrm{Cd}$ adsorption rate up to $83.56 \%$, and also resistant to other heavy metals such as $\mathrm{Pb}, \mathrm{Zn}$, and $\mathrm{Cu}$. When $\mathrm{Cd}^{2+}$ concentration ranged from 2 to $5 \mathrm{mM}$, the fungal colony changed from yellow/green to red. The colony morphology was also affected by $\mathrm{Cd}^{2+}$ concentrations with protuberances forming on the colony surface at $20 \mathrm{mM}$. The strain $\mathrm{CN} 35$ was found to grow well at pH 4 to 8 at between $24^{\circ} \mathrm{C}$ and $37^{\circ} \mathrm{C}$, and the optimal growth conditions were established to be at $\mathrm{pH} 4$ and $30^{\circ} \mathrm{C}$. Fermented liquid of the strain is neither disease-causing nor inhibitory to rice seedling emergence, but rather improves rice seedling and root growth and enhances rice detoxification ability under Cd stress. Thus, the Cd-resistant fungus CN35 has the potential to treat $\mathrm{Cd}$-polluted rice paddies.
\end{abstract}

Keywords: paddy soil, Cd pollution, Penicillium sp., Cd adsorption

\section{Introduction}

Cadmium $(\mathrm{Cd})$ is one of the most toxic heavy metal elements in soil environment due to its strong chemical activity, large mobility, persistent toxicity, and nonbiodegradability [1-2]. It is easily absorbed by organisms from the environment and eventually enters the human body through the food chain. $\mathrm{Cd}^{2}+$ can cause itai-itai

*e-mail:zhouxm1972@126.com

**e-mail: bailianyang2005@aliyun.com disease and also form unstable adducts by covalent binding with adenine, guanine, adenosine, and deoxyguanosine, so as to damage DNA [3]. It contributes to violence and other mental disorder disease-related behaviors [4-5]. According to the recent research data of epidemiology, people exposed to $\mathrm{Cd}$ through diet are prone to have higher risks of endometrial cancer [6], breast disease [7], prostate cancer, and osteoporosis [8]. Because of its hazardous nature in human health, $\mathrm{Cd}$ has been identified as a Class 1 (human) carcinogen by the international cancer research agency [9]. 
Discharge of Cd-containing pollutants into the soil, like industrial wastes (gas, water, etc.), agricultural wastes, and sewage produced by human activities, ultimately contaminates the paddy fields and becomes a more and more serious and common problem across the world. Therefore, it is necessary and urgent to treat $\mathrm{Cd}$ pollution on rice. Cd pollution on rice is mainly and directly caused by soil contamination, so Cd-polluted paddy soil is the key to remedy [10].

Traditional physical and chemical remediation methods that are still used today consume large amounts of energy or chemicals and incur high economic costs [11]. Some passivating agents can even cause adverse effects on physical and chemical soil properties during remediation, thus affecting the the soil for subsequent use [12]. Microorganisms are in a big quantity with large specific surface area and high metabolic activity. They interact with heavy metals through a variety of mechanisms: biosorption, cellular sequestration, antioxidant defense, crystallization, chelation, chemical form change, ion exchange, precipitation inside and outside the cell and cell wall, or pigment adsorption to reduce the heavy metal contents in the environment or change their biological effectiveness [13-15]. Thus, microbial remediation is better than the physical and chemical remediation technologies due to its simple operation, low treatment cost, and desirable effect. A large amount of polysaccharides and glycoproteins were included on the fungal cell wall, such as dextran, chitin, mannan, mannan phosphate, etc. Those polymers provide a number of metal ligands, which can fully combine with heavy metals and reduce the heavy metal ions that are active and free in the soil, which in turn reduces the content of the pollutants that are available in the soil. In addition, there occurs no secondary pollution to the environment. Most fungi have the mycelial structure and the mycelium can penetrate into the polluted soil and have physical and chemical reactions with heavy metals. Fungi, due to their wide source distribution, low sensitivity to the changes of nutrients, ventilation, temperature and $\mathrm{pH}$, and easy fermentation, are considered to be the most suitable organisms for mass production at a lower cost. Multiple advantages in economy, ecology, and production give fungi great potential in heavy metal pollution mitigation [16]. Because of the long-term selection effects of the environment, Cd-resistant fungi with strong $\mathrm{Cd}$ adsorption capacity may exist in a Cd-polluted environment. Fungi with high $\mathrm{Cd}$ resistance and $\mathrm{Cd}$ adsorption capacity that have been screened from wastewater and soil in industrial and mining areas at home and abroad include aspergillus foetidus [17], penicillium, and yeast [18], but only a few have been screened from paddy soil. Local Cd-resistant microorganisms with high adsorption capacities for heavy metals can better adapt to the special environment of heavy metal-polluted paddy soil [19], so as to play a role in biological adsorption. Therefore, screening Cd-resistant fungi in Cd-polluted paddy soil and studying their $\mathrm{Cd}$ adsorption characteristics have important theoretical and practical significance in the remediation of Cd-polluted paddy soil.
This current research screened and identified Cdresistant fungi from Cd-polluted paddy soil in Changning, Hunan Province, China, and studied their Cd adsorption capacities, their resistance to $\mathrm{Cd}$ and other common heavy metals, and evaluated the heavy metal resistance of the strains with minimum inhibition concentration as the heavy metal resistance index [20]. This research also studied the external performance of Cd-resistant fungi responses to $\mathrm{Cd}$ stress, and their role in growing the rice safety and rice detoxification under $\mathrm{Cd}$ stress. Our long-term aims are to obtain potential strains for effective treatment of $\mathrm{Cd}$ polluted soil, to expand the fungus resource library for microbial remediation of the Cd-polluted paddy soil, to explore the growth conditions, and finally to provide the theoretical basis for cultivating and further exploring $\mathrm{Cd}$ pollution treatment in a paddy environment by the fungal strains.

\section{Material and Methods}

\section{Isolation of the Cd-resistant Fungus}

The soil sample was collected from the paddy field in Xiangjiang River Basin in Xintong Village, Songbai Town, Changning City, Hunan Province, China $\left(26^{\circ} 34^{\prime} 36.27^{\prime \prime} \mathrm{N}, 112^{\circ} 36^{\prime} 08.73^{\prime \prime} \mathrm{E}\right)$. Two $\mathrm{kg}$ of 5 to 20 -cmdeep soil was collected from the paddy field from one lateseason cropping. The soil was mixed well and then put in two sterile sealable bags. One bag was put in an ice box and brought back to the lab for storage at $4{ }^{\circ} \mathrm{C}$ and the other aired to determine the heavy metal contents and $\mathrm{pH}$ of the soil. Ten $\mathrm{mg}$ of the $4^{\circ} \mathrm{C}$ stored soil was dissolved in $90 \mathrm{~mL}$ of sterile deionized water and magnetically stirred for $30 \mathrm{~min}$ to prepare the soil suspension. One $\mathrm{mL}$ of the soil suspension was taken and inoculated into PDA liquid medium containing $2 \mathrm{mM}$ of $\mathrm{Cd}\left(\mathrm{NO}_{3}\right)_{2}$. Streptomycin (30 $\mathrm{mg} / \mathrm{L})$ was added to inhibit fungal growth. The Cd-resistant fungus was accumulated in $28^{\circ} \mathrm{C}$ in an oscillation incubator under $150 \mathrm{rpm}$, after which $100 \mu \mathrm{L}$ of $\mathrm{Cd}$-resistant fungus enrichment culture diluent was coated on $2 \mathrm{mM} \mathrm{Cd}^{2+}$ PDA plate. After $7 \mathrm{~d}$ at $28^{\circ} \mathrm{C}$, the colonies were well grown and switched to the $\mathrm{Cd}^{2+}$ PDA plates at higher concentrations $(4,8$, and $16 \mathrm{mM})$ sequentially for gradient domestication and cultivation to further screen, isolate, and purify the Cd-resistant fungi. Finally, the strains with strongest resistance to $\mathrm{Cd}$ were obtained as the test strains for further research.

\section{Cd-Resistant Fungus Identification}

\section{Morphological Analysis}

CN35 was inoculated on Czapek yeast autolysate agar (CYA), malt extract agar (MEA, Oxoid), oatmeal agar (OA), yeast extract sucrose agar (YES), and CYA with $5 \% \mathrm{NaCl}$ (CYAS) on medium plates (diameter: $90 \mathrm{~mm}$ ) using the three-point inoculation method [21]. After 7d at $25^{\circ} \mathrm{C}$, the colony diameters were measured and checked 
for the sporulation situation by observing the colony color at front and back surfaces and the soluble pigments. The colony material grown on MEA plate for $7 \mathrm{~d}$ was observed microscopically. The colony material grown on the OA plate was used for observing ascocarp, asci, and ascospore. Microstructure observation was carried out by scanning electron microscopy (SEM).

\section{DNA Extraction, PCR Amplification, and Phylogenetic Analysis}

DNA was extracted from a week-old colony grown on PDA using an Omega E.Z.N.A. Fungal DNA Kit (Omega, USA). One-hundred mg of fungal hypha was picked using a sterilization toothpick. The most widely used fungus tag sequence was used for an internal transcribed spacers region (ITS) sequence. $\beta$-tubulin (BenA) was the best choice for the fungus secondary identification tag [22]. We used ITS universal primers ITS-1 (5'-TCCTCCGTAGGTGAACCTGCGG-3') and ITS-4 (5'-TCCTCCGCTTATTGATATGC-3') [21]. Based on the $\beta$-tubulin sequences of GenBank, a pair of primers was designed as follows: Bt2a (5'-GG TAACCAAATCGGTGCTGCTTTC-3') and Bt2b ( 5 ' - A C C C TCA GT GTA GT GA CCCTTGGC-3') [23] and used for amplification. PCR reaction conditions were as follows: degeneration at $95^{\circ} \mathrm{C}$ for $5 \mathrm{~min}$, cycling 35 times, denaturation at $94^{\circ} \mathrm{C}$ for $45 \mathrm{~s}$, annealing at $55^{\circ} \mathrm{C}$ for $45 \mathrm{~s}$, extension at $72^{\circ} \mathrm{C}$ for $1 \mathrm{~min}, 72^{\circ} \mathrm{C}$ for $7 \mathrm{~min}$, and termination at $10^{\circ} \mathrm{C}$. The sequences of PCR products were determined by Sangon Biotech Engineering (Shanghai) Co., Ltd. The ITS and $\beta$-tubulin gene sequences of the fungus were submitted to GenBank and analyzed by the BLAST search tool. ITS and BenA gene sequences were compared to obtain $t$ he reference sequence for phylogenetic analysis, for which we used the neighbor-joining (NJ) method in Mega 5.0.

\section{Cd Adsorption Capacity Test}

The adsorption process was performed in a $25 \mathrm{~mL}$ conical flask with $100 \mathrm{~mL}$ of PDA liquid medium. CN35 grown for $7 \mathrm{~d}$ on the plate without $\mathrm{Cd}^{2+}$ was scraped into a flask. After growing for $7 \mathrm{~d}$ at $150 \mathrm{rpm}$ and $28^{\circ} \mathrm{C}$, it was centrifuged at 8,000 rpm for $15 \mathrm{~min}$. Then, $0.1 \mathrm{~g}, 0.5 \mathrm{~g}$, $1 \mathrm{~g}$, and $1.5 \mathrm{~g}$ of hypha (taking $1 \mathrm{~g}$ wet hypha and putting it in the oven for drying at $60^{\circ} \mathrm{C}$ until the hypha weight was constant, calculating the dry weight of the wet hypha) were taken under aseptic conditions to inoculate into $100 \mathrm{mg} / \mathrm{L}$ and $200 \mathrm{mg} / \mathrm{L} \mathrm{Cd}^{2+}$ PDA liquid mediums, respectively. To avoid adsorption of the $\mathrm{Cd}^{2+}$ by the medium, $100 \mathrm{mg} / \mathrm{L}$ and $200 \mathrm{mg} / \mathrm{L} \mathrm{Cd}^{2+}$ PDA liquid mediums without hypha were taken as the control, respectively. After growing for $7 \mathrm{~d}$ at $150 \mathrm{rpm}$ and $28^{\circ} \mathrm{C}$, they were centrifuged at 8,000 rpm for $15 \mathrm{~min}$. The $\mathrm{Cd}^{2+}$ concentrations in the supernatants were determined using atomic absorption spectrophotometry. We calculated $\mathrm{Cd}$ adsorption rates of the strains using the following formula
[24]. All the tests were repeated twice and we used the averages of the results for data analysis.

Calculation formula: $\operatorname{Ar}(100 \%)=\left(\mathrm{C}_{\mathrm{c}}-\mathrm{C}_{\mathrm{t}}\right) / \mathrm{C}_{\mathrm{c}} \times 100 \%$, where $\mathrm{C}_{\mathrm{c}}$ is the $\mathrm{Cd}^{2+}$ final concentration in the control supernatant $(\mathrm{mg} / \mathrm{L})$ and $\mathrm{C}_{\mathrm{t}}$ is the $\mathrm{Cd}^{2+}$ concentration in the supernatant after hypha adsorption $(\mathrm{mg} / \mathrm{L})$.

\section{Cd Resistance and Other Heavy Metal Resistance Test}

$\mathrm{CN} 35$ isolated from $16 \mathrm{mM} \mathrm{Cd}^{2+}$ plate was taken to be inoculated on the PDA plates with $\mathrm{Cd}^{2+}$ concentrations of $20,25,30,35,40$, and $45 \mathrm{mM}$ and grown at $28^{\circ} \mathrm{C}$ for $7 \mathrm{~d}$ until the colonies showed no growth. At this time, $\mathrm{Cd}^{2+}$ concentrations of the plates were MIC values of $\mathrm{Cd}$ to CN35. The fungal discs were punched on the PDA plate with CN35 single colony by a punch at a diameter of $5 \mathrm{mM}$ and then inoculated on $\mathrm{Pb}\left(\mathrm{NO}_{3}\right)_{2}(\mathrm{mM}: 0,20,40,60$, 80, etc.), $\mathrm{ZnSO}_{4}$ (mM: 0, 20, 40, 60, and 80 etc.), $\mathrm{CuSO}_{4}$ (mM: 0, 5,10, 20, 30, 40, etc.) PDA plates, respectively, and grew at $28^{\circ} \mathrm{C}$ for $7 \mathrm{~d}$. The colony diameters were determined by the straightedge crossing method (the same below), to explore the resistance of CN35 to other several common heavy metals in Cd-polluted paddy fields, namely measuring the MIC values. All tests were repeated twice.

\section{The Response of CN35 to $\mathrm{Cd}^{2+}$ Stress of Different Concentrations}

$\mathrm{CN} 35$ was inoculated on $\mathrm{Cd}^{2+} \mathrm{PDA}$ and CYA plates (to avoid interference of other heavy metal ions on results, the components required by the medium-trace elements $\mathrm{Zn}$ and $\mathrm{Cu}$ were not added) at $0,0.25,0.5,1,2,5,10$, 14,20 , and $40 \mathrm{mM}$, respectively, with three replicates per treatment. After growing at $28^{\circ} \mathrm{C}$ for $7 \mathrm{~d}$, the diameters were determined and we recorded the sporulation situation, color, and pigment secretion differences.

\section{Effect of $\mathrm{pH}$ and Temperature on Strain Growth and Cd Resistance}

$\mathrm{CN} 35$ was inoculated on $2 \mathrm{mM}$ PDAs with/without $\mathrm{Cd}^{2+}$ with $\mathrm{pH}$ values of $4.0,5.0,6.0,7.0$, and 8.0 according to the above method, and repeated twice each. CN35 were cultivated at $28^{\circ} \mathrm{C}$ inversely. After $7 \mathrm{~d}$, the diameters of the colonies were determined and the colony differences observed. CN35 was inoculated on $2 \mathrm{mM}$ natural $\mathrm{pH}$ PDAs without $\mathrm{Cd}^{2+} /$ with $\mathrm{Cd}^{2+}$ and cultivated at $37^{\circ} \mathrm{C}$, $32^{\circ} \mathrm{C}, 30^{\circ} \mathrm{C}, 28^{\circ} \mathrm{C}, 24^{\circ} \mathrm{C}$, and $20^{\circ} \mathrm{C}$, respectively, repeating twice each. They were cultivated inversely for $7 \mathrm{~d}$ and then the diameters of the colonies were determined and the colony difference observed.

\section{Rice Growth Security Detection of CN35 and its Detoxification Effect on Rice under Cd Stress}

The hypothesis for microorganisms to be used in the paddy field for Cd pollution control is its security to rice 
growth without causing diseases or inhibiting growth. Some pathogenic penicillium fungi often cause crop rotting and pathogenesis in nature. Some penicilliums even produce toxins affecting crop growth. Seedlings are sensitive to environmental stress conditions, so it is necessary to examine the pathogenic condition of $\mathrm{CN} 35$ on rice and its influence on seedling emergence, plus radical and seedling growth. The experiment was processed according to the design test in Group A. At the same time, Group B was designed to be processed to explore whether CN35 has the detoxification effect on rice under Cd stress. The planting soil was collected from the paddy field of the Hunan Academy of Agricultural Sciences (Cd content: $0.28 \mathrm{mg} / \mathrm{kg}$ ). Two hundred $\mathrm{mg}$ of air-dried soil was added in $200 \mathrm{ml}$ beakers. CN35 fermented liquid (CN35 was inoculated on PDA liquid medium at $150 \mathrm{rpm}$ and shaken at $30^{\circ} \mathrm{C}$ to grow for $7 \mathrm{~d}$ ) was added before sowing and stirred well. Ten germinating rice seeds were added ( $2 / 3$ of the seed length) to each beaker. Each treatment was repeated twice. Group A treatment included 0, 20, 40,60 , and $80 \mathrm{~mL}$ of CN35 fermented liquids. In Group roup $\mathrm{B}$ treatment: $\mathrm{CdCl}_{2}$ solution was added in each beaker to bring the $\mathrm{Cd}^{2+}$ concentration of the soil to $200 \mathrm{mg} / \mathrm{kg}$, and $0,20,40$, and $80 \mathrm{~mL}$ of CN35 fermented liquids were added to $\mathrm{CdCl}_{2}$ solution, supplemented with sterile deionized water for each to make the total volume $120 \mathrm{~mL}$, mixing thoroughly and then pouring into the beaker and stirred well. Germinating rice seeds were cultivated in Group A and B solutions alternating for $12 \mathrm{~h}$ day $\left(32^{\circ} \mathrm{C}\right)$ and night $\left(26^{\circ} \mathrm{C}\right)$. After $2 \mathrm{~d}$ we calculated rice seedling emergence rates. After $8 \mathrm{~d}$ we calculated the lengths and fresh weights of rice seedlings and the fresh weights of the roots. Then we obtained the average seedling and root lengths.

\section{Results and Discussion}

\section{Soil Sample and Isolation of the Cd-Resistant Fungus}

Total contents $\mathrm{Cd}, \mathrm{Cu}, \mathrm{Zn}$, and $\mathrm{Pb}$ in the soil sample were $17.73,32.42,103.9$, and $58.2 \mathrm{mg} / \mathrm{kg}$, respectively, and the $\mathrm{pH}$ of the soil remained at 6.1. The Cd-resistant fungi were screened step by step by using the $\mathrm{Cd}$ ion concentration gradient domestication method. Finally, 10 fungal strains were obtained from a $2 \mathrm{mM} \mathrm{Cd}^{2+}$ plate and they were transferred to $\mathrm{Cd}^{2+}$ plates at $4 \mathrm{mM}$ and $8 \mathrm{mM}$. Among them, the resistance of six strains was reduced gradually and that of the other four strains was still strong. The four strains were transferred to a $16 \mathrm{mM}$ $\mathrm{Cd}^{2+}$ plate. Among them, three strains did not grow and only one grew. The strain with the strongest $\mathrm{Cd}$ resistance was selected as the test strain for further research, which was numbered as CN35.

The collected soil was acidic and polluted by $\mathrm{Cd}$ but not by other heavy metals. The fungi with $\mathrm{Cd}$ resistance capacity of $2 \mathrm{mM}$ (six strains), $8 \mathrm{mM}$ (three strains), and $16 \mathrm{mM}$ (one strain) were screened from Cd-polluted soil. These results indicated that microorganisms in $\mathrm{Cd}$-polluted soil had different $\mathrm{Cd}$ resistance levels.

\section{Identifying the Cd-Resistant Fungus}

\section{Morphological Characteristics}

Colony characteristics: the CN35 colony, especially its center, was in the loose floccus or rope shape on the CYA, MEA, and OA plates. It showed low, clear, and neat edges and large amounts of green spores. The edge hypha was white and at a later growth stage it became dark green with red droplets on the surface (Fig. 1a). It was white to reddish brown on the back of the CYA plate and sage green to reddish on the back of the MEA and OA plates (not shown in the picture). CN35 could grow on the CYAS plate with its salt-resistant ability.

Micro morphological characteristics: there were broom-like branch wheels on the tip of conidiophore that were mainly bicyclic. The vial was in the lanceolate shape. The chain-like globular conidias were produced at the top of the sterigma with diameters of 2.5 to $3 \mu \mathrm{m}$ (Fig. 1b). The hypha had the septum (Fig. 1c). Those morphological characteristics were consistent with those of penicillium. No ascocarp was observed on OA where CN35 grew for $14 d$.

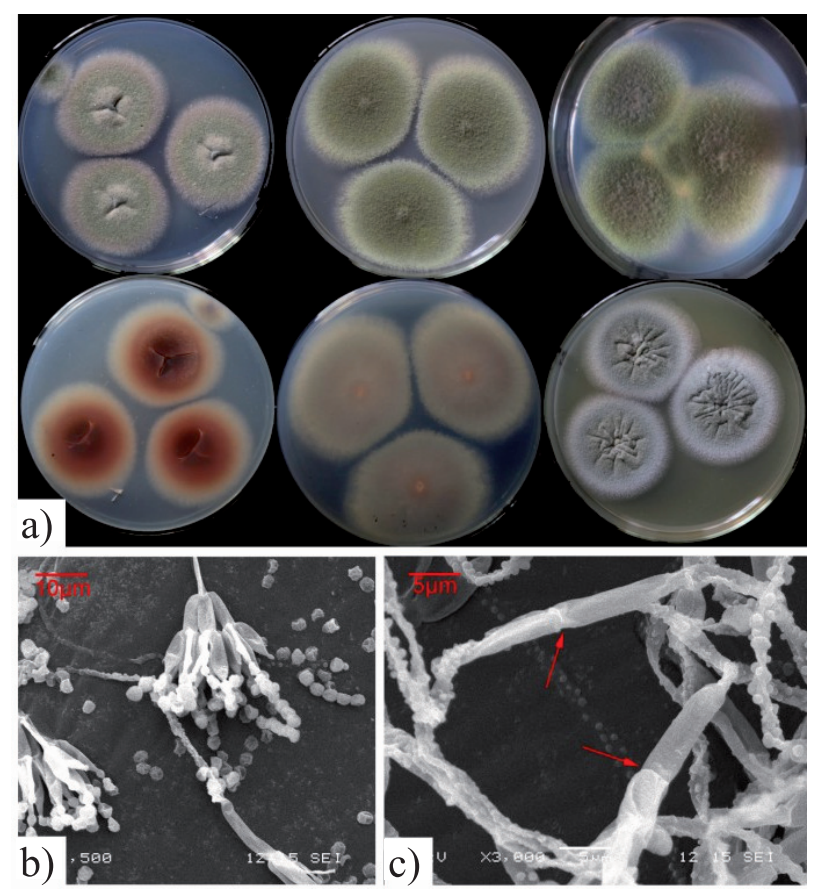

Fig. 1. a) Morphological characteristics of CN35 grown on different medium plates. Medium in the top three plates (from left to right) is CYA, MEA, and OA; medium in the bottom three plates is (left to right) CYA reverse, MEA reverse and YES, b) Conidiophore (broom-like branch wheels) and conidium (chainlike globular), c) Septate hypha (indicated by the red arrows). 


\section{Comparison of ITS and BenA Gene Sequences and Phylogenetic Analysis}

The comparative analysis of the sequences in the NCBI BLAST showed that up to $99 \%$ homology of ITS and BenA gene sequences of CN35 to Penicillium sp. and its teleomorph sp. Talaromyces sp. The phylogenetic diagrams of the ITS sequence and BenA gene sequence were constructed using MEGA5.0 software (Figs 2-3), which confirmed that CN35 was very close to the phylogeny of Penicillium sp. and Talaromyces sp. Based on the morphological observation and molecular biological analysis results, CN35 was preliminarily identified as belonging to Penicillium sp. [25].

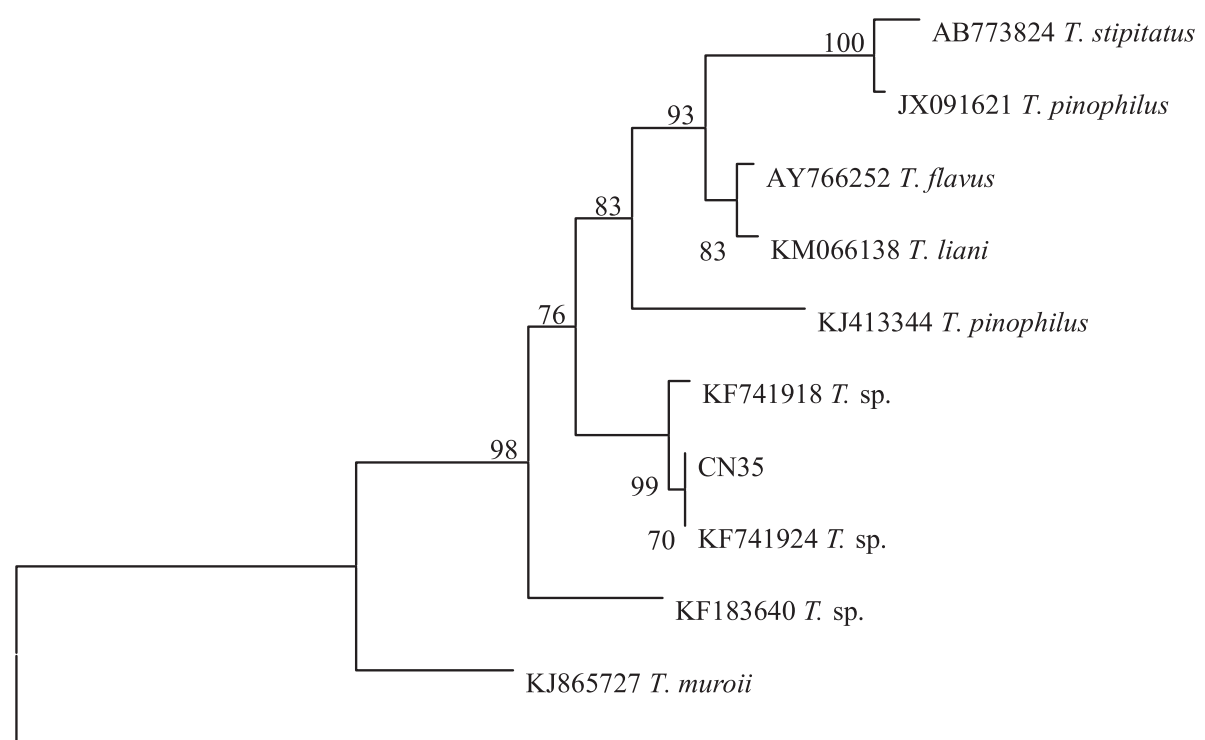

JX091391 T. dendriticus

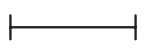

0.02

Fig. 2. Phylogenetic tree based on ITS region gene sequence of the fungus CN35, the scale bar corresponds to nucleotide sequence difference. Bootstrap values above the cut-off ( $70 \%)$ are shown.

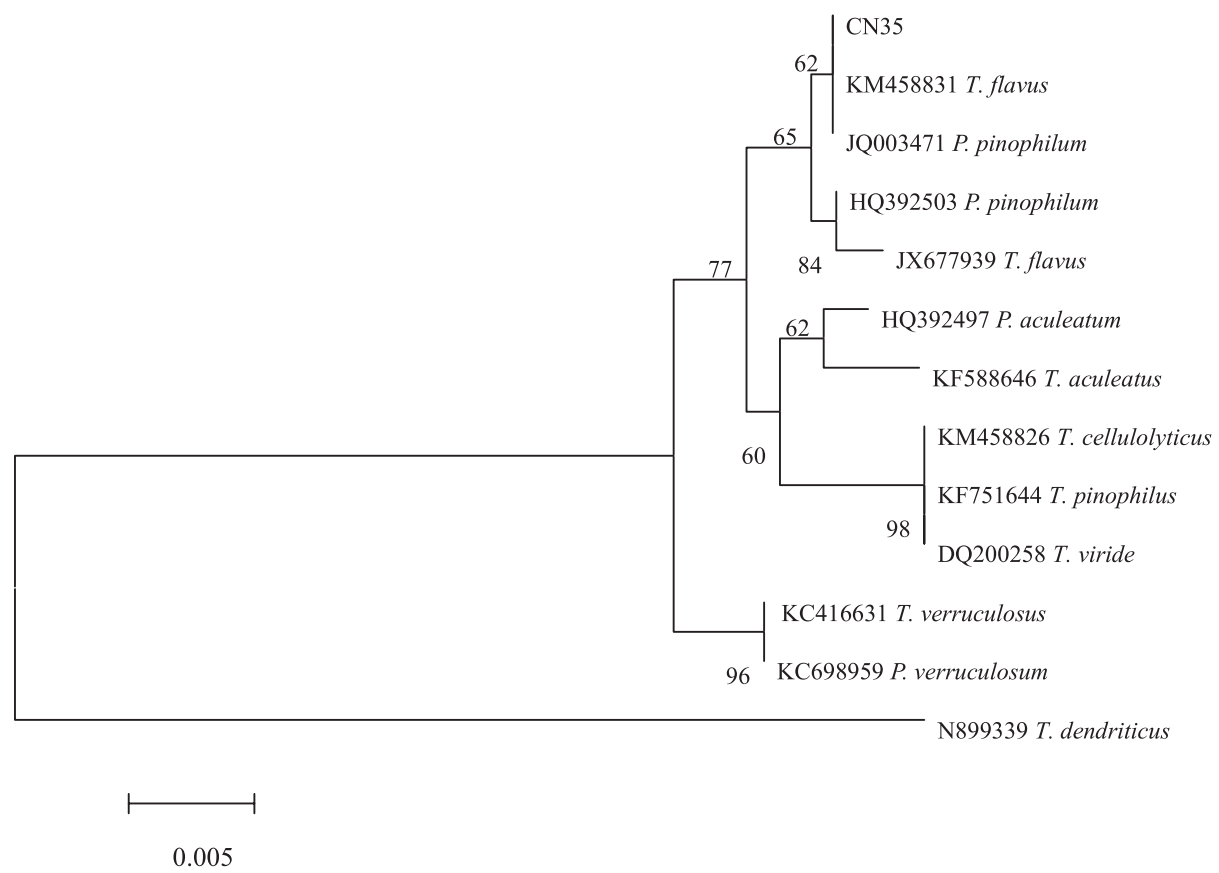

Fig. 3. Phylogenetic tree based on BenA gene sequence of the fungus CN35; the scale bar corresponds to nucleotide sequence difference. Bootstrap values above the cut-off $(60 \%)$ are shown. 
The morphological characteristics of CN35 with strongest resistance were consistent with those of Penicillium sp. fungi. The sequence was amplified based on the ITS region and BenA gene sequence, which are the most widely used in fungal identification. The phylogenetic tree was constructed and based on morphological characteristics and phylogenetic analysis, and CN35 was preliminarily identified to be Penicillium sp. fungus.

\section{Cd Adsorption Capacity of CN35}

In the medium where the initial concentration of $\mathrm{Cd}^{2+}$ was $100 \mathrm{mg} / \mathrm{L}$ without hypha, the concentration of $\mathrm{Cd}^{2+}$ stayed at $95.77 \pm 2.6 \mathrm{mg} / \mathrm{L}$. For the medium where the initial concentration of $\mathrm{Cd}^{2+}$ was $200 \mathrm{mg} / \mathrm{L}$, the concentration of $\mathrm{Cd}^{2+}$ remained at $196.87 \pm 5.11 \mathrm{mg} / \mathrm{L}$. From Fig. 4, when the initial concentration was $200 \mathrm{mg} / \mathrm{L}$ and $1.5 \mathrm{~g}$ of wet hypha was added (the moisture content of the fresh hypha was $83 \%$ ), the $\mathrm{Cd}$ adsorption rate was the highest. The difference was not significant between $\mathrm{Cd}$ adsorption rates when adding $0.5 \mathrm{~g}$ and $1.0 \mathrm{~g}$ of wet hypha at the same initial concentration. When the adding amount of hypha was fixed, the Cd adsorption rate of CN35 was greater in the medium with the concentration of $\mathrm{Cd}^{2+}$ of $200 \mathrm{mg} / \mathrm{L}$. When the initial concentration of $\mathrm{Cd}^{2+}$ was $200 \mathrm{mg} / \mathrm{L}$, after adding $0.5 \mathrm{~g}$ of hypha, the $\mathrm{Cd}$ adsorption rate of CN35 was increased compared with that when $0.1 \mathrm{~g}$ of hypha was added. When the initial concentration of $\mathrm{Cd}^{2+}$ was fixed, the $\mathrm{Cd}$ adsorption rate of $\mathrm{CN} 35$ was increased with the increased amount of adding hypha. However, if it continued to increase the amount of hypha, the increased $\mathrm{Cd}$ adsorption rate showed no significance. The $\mathrm{Cd}$ adsorption rate increased with increased

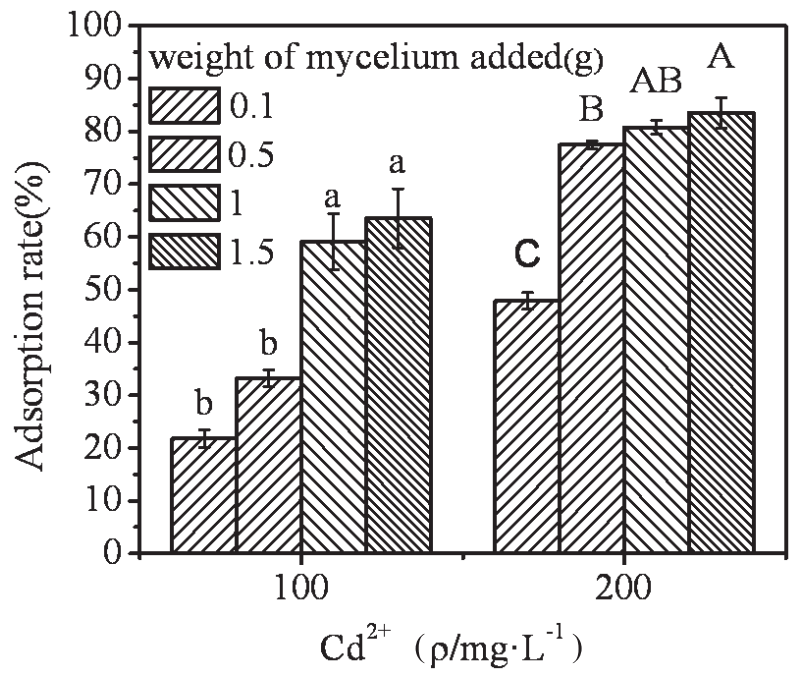

Fig. 4. Adsorption rates of $\mathrm{CN} 35$ under different adding amounts of hypha and different initial concentrations of $\mathrm{Cd}^{2+}$. Different letters (lowercase/uppercase) above the columns indicate significant differences between treatments according to Duncan's multiple range test at $\mathrm{P}<0.05$ level and $\mathrm{n}=3$; vertical bars are standard error of the mean. concentrations of $\mathrm{Cd}^{2+}$, at the same hypha amount. The highest adsorption rate detected was $83.56 \%$, when $1.5 \mathrm{~g}$ hypha was added to $200 \mathrm{mg} / \mathrm{L}$ PDA medium.

In the $\mathrm{Cd}$ adsorption test, when the same amount of hypha was added, the higher the $\mathrm{Cd}^{2+}$ concentration, the higher the $\mathrm{Cd}$ adsorption rate of the strain. Perhaps the higher the concentration, the greater the contact area of hypha with $\mathrm{Cd}$ ions - which is beneficial for absorbing more $\mathrm{Cd}^{2+}$. When the initial concentration of $\mathrm{Cd}^{2+}$ was constant, the $\mathrm{Cd}$ adsorption rate of $\mathrm{CN} 35$ did not continue to increase significantly with the increasing weight of hypha. This might be due to the limited nutrients that prevented the infinite reproduction of the strains. Then the amount of hypha no longer increased significantly, and neither did the contact area between the hypha and $\mathrm{Cd}^{2+}$. As a result, the $\mathrm{Cd}$ adsorption rate did not increase significantly. For $100 \mathrm{~mL}$ PDA medium at $200 \mathrm{mg} / \mathrm{L}$, the addition of only $0.3 \mathrm{~g}$ (dry weight) of hypha could make the $\mathrm{Cd}$ adsorption rate reach the maximum of $83.56 \%$. Many Cd-resistant fungi screened from the Cd-polluted environment showed strong $\mathrm{Cd}$ adsorption capacity, such as Cd-resistant penicillium. Dugal [26] and Hemambika [27] obtained the Cd-resistant penicillium strains from the industrial factory and electroplating industrial park that were polluted by $\mathrm{Cd}$. The Cd-resistant fungi were screened from the Cd-polluted paddy soil, which could achieve a significant $\mathrm{Cd}$ adsorption effect by adding only a small amount of hypha. This proved that penicillium had the high $\mathrm{Cd}$ adsorption ability and could be used as potential fungi for Cd-polluted soil remediation.

\section{Cd Resistance and Other Heavy Metal Resistance Test}

$\mathrm{CN} 35$ could barely grow on the $\mathrm{Cd}^{2+}$ plate at $45 \mathrm{mM}$. When the concentration of $\mathrm{Cd}^{2+}$ was $46 \mathrm{mM}$, no colony growth was observed. Thus, the MIC value of $\mathrm{Cd}$ was $46 \mathrm{mM}$ and the highest resistance of CN35 strain to $\mathrm{Cd}^{2+}$ was up to $45 \mathrm{mM}$. Only a few microorganisms had such a high level of Cd resistance ability [17].

According to Fig. 5, with the higher concentrations of heavy metal ions, the diameters of the colonies decreased, indicating that various heavy metals showed the inhibitory effects on the growth of CN35 strain. When $\mathrm{Cu}^{2+}$ concentration was $20 \mathrm{mM}$, no colony growth was observed. When $\mathrm{Pb}^{2+}$ and $\mathrm{Zn}^{2+}$ concentrations were $80 \mathrm{mM}$, the colonies could grow, but were obviously inhibited. There was only a small amount of hypha without colony. The inhibitory effect of $\mathrm{Pb}^{2+}$ on $\mathrm{CN} 35$ was smaller than that of $\mathrm{Zn}^{2+}$. The MIC values $(\mathrm{mM})$ of $\mathrm{Cu}$, $\mathrm{Zn}$, and $\mathrm{Pb}$ to $\mathrm{CN} 35$ were $20,>80$, and $>80$, respectively. MIC value indicate the resistance level of CN35 strain to heavy metals. Thus the resistance of CN35 to the abovementioned heavy metals was ranked as $\mathrm{Pb}^{2+}>\mathrm{Zn}^{2+}>\mathrm{Cd}^{2+}$.

As several other heavy metals were found in the $\mathrm{Cd}$ pollution source, Cd-polluted soil is often polluted by several heavy metals. The MIC values of $\mathrm{Pb}, \mathrm{Zn}$, and $\mathrm{Cu}$ were $>80,>80$, and $20 \mathrm{mM}$, respectively. They were much higher than the secondary standard concentration 


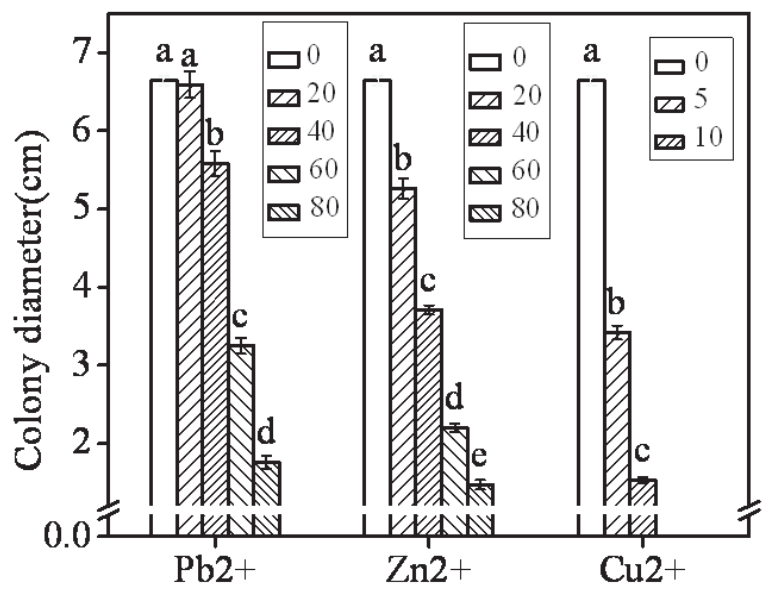

Heavy metal concentration(mM)

Fig. 5. Influence of different heavy metal ions on the growth of CN35 Strain. Different letters above the columns (the same metal ion) indicate significant differences between treatments according to Duncan's multiple range test at $\mathrm{P}<0.05$ level and $\mathrm{n}=3$; vertical bars are standard error of the mean.

of China's soil environment quality $(\mathrm{pH} \leq 6.5, \mathrm{mg} / \mathrm{kg}$, Pb: 250, Zn: 200, Cu: 50, Cd: 0.3). This indicated that the strain had strong resistance to those heavy metals. Penicillium belongs to filamentous fungus and its filamentous structure may be conducive to resisting the stress of high-concentration $\mathrm{Cd}$ and other heavy metals. The Cd-resistant fungus demonstrated the potential to resist several heavy metals when being used for restoring a Cd-polluted environment.

\section{Response of CN35 Strain to $\mathrm{Cd}^{2+}$ Stress of Different Concentrations}

The color of the colony greatly varied at different concentrations of $\mathrm{Cd}^{2+}$, but $\mathrm{Cd}^{2+}$ seems to increase the red pigment. On PDA, the surface of the control colony was covered with light green conidiums, among which the color of central spores was deep. When the concentration of $\mathrm{Cd}^{2+}$ was greater than 0 and smaller than $5 \mathrm{mM}$, the green of the colony deepened and the white hypha at the end of the colony was extended outward. With increases in $\mathrm{Cd}^{2+}$ concentrations, the conidiums of the colony were reduced. When the concentration was $5 \mathrm{mM}$, only sparse spores existed at the central surface of the colony and the front of the colony was red (Fig. 6a). When the red colony was transferred back to the Cd-free plate, it was grown well with neat surface and green in color (not shown in the picture). On CYA (without trace elements), the control colony was yellow, and the colony turned red, which deepened with the increase of the $\mathrm{Cd}^{2+}$ addition (Fig. 6b). On the back of the colony (Fig. 6c), the color of the control colony was red in the center. With the increase in $\mathrm{Cd}^{2+}$ concentration, the red scope extended from the center to the outside, the color deepened, and the white edge was reduced. The colony morphology was also changed with the concentration of $\mathrm{Cd}^{2+}$ and the combination between the colony and the medium was correlated. For example, when the concentration of $\mathrm{Cd}^{2+}$ in PDA was $10 \mathrm{mM}$, the colony was neat. When at $20 \mathrm{mM}$, the colony surface changed to umbilicate bulge (Fig. 6d), and the back was cracked radially.

The strain grew fast on the PDA solid medium. After growing at $28^{\circ} \mathrm{C}$ for $3 \mathrm{~d}$, the colony diameter was about
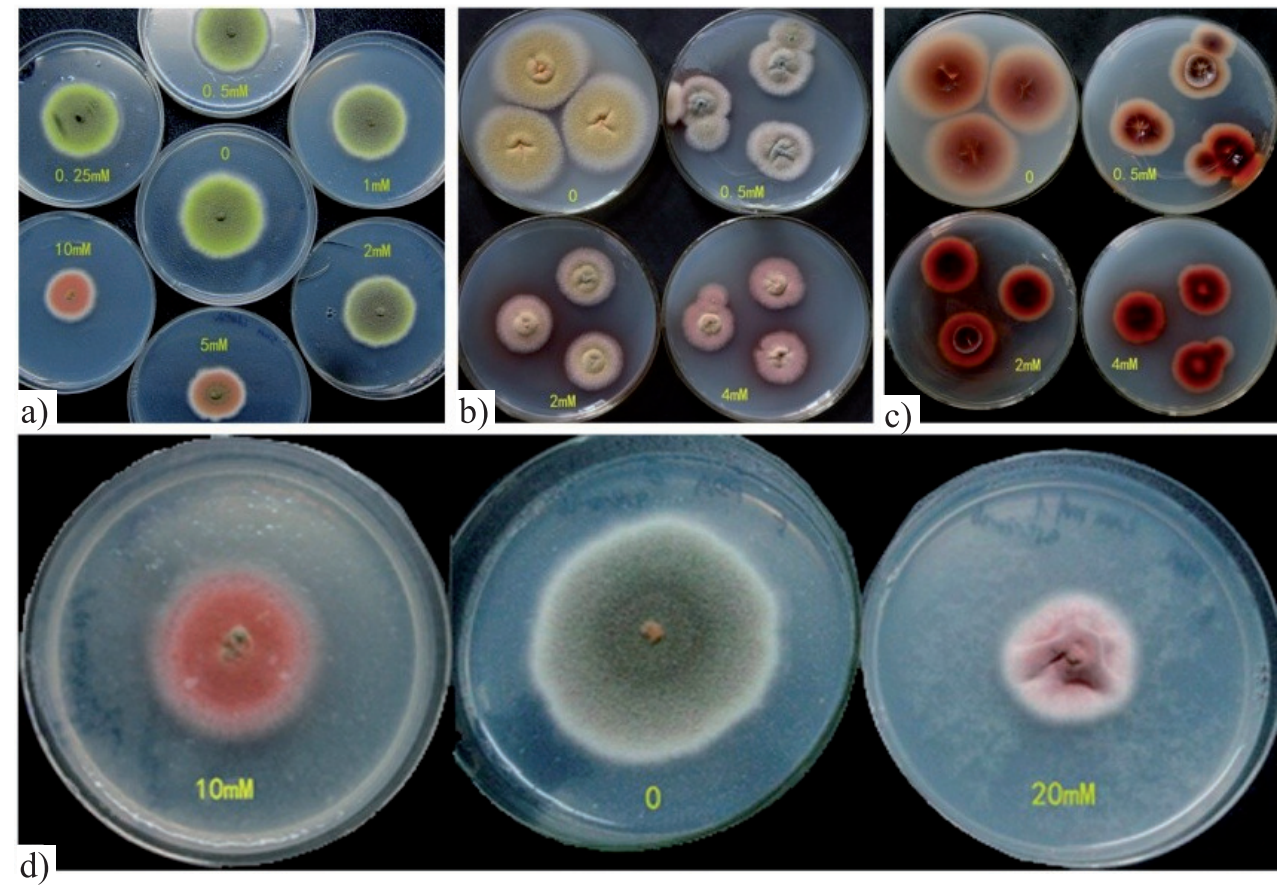

Fig. 6. Colony color and morphological difference of CN35 on PDA and CYA mediums with different concentrations of $\mathrm{Cd}^{2+}$. Colony a) PDA, b) CYA, c) CYA (reverse), and d) PDA (0: green, neat surface; $10 \mathrm{mM}$ : red, neat surface; $20 \mathrm{mM}$ : red, umbilicate bulge). 
$22 \mathrm{mM}$. After $12 \mathrm{~d}$, the plate with the diameter of $9 \mathrm{~cm}$ was covered with colonies. The diameter of the colony on the plate medium could reflect the biomass of fungal growth [9]. $\mathrm{Cd}^{2+}$ had an inhibitory effect on colony diameter. $\mathrm{Cd}^{2+}$ at 0.25 to $0.5 \mathrm{mM}$ demonstrated little impact on the colony diameter of $\mathrm{CN} 35$, while the $\mathrm{Cd}^{2+}$ concentration was $\geq 2 \mathrm{mM}$. Different concentrations of $\mathrm{Cd}^{2+}$ showed significant inhibitory effects on the colony diameter of CN35 ( $<<0.05$, the same below; Fig. 7). The difference between the diameter and the control was significant, and when the concentration of $\mathrm{Cd}^{2+}$ reached $40 \mathrm{mM}$, the colony could still grow well, indicating that the strain had strong Cd resistance.

Since excessive heavy metals are not necessary for a microorganism to live, they often respond to heavy metal stress by changes in growth, morphology, and microstructure, and production of secretions [28]. Some changes that can help adapt to the heavy metal-polluted environment may enhance their resistance. It has been reported that the colony color of $\mathrm{Cd}$ microorganisms on the medium with a certain concentration of $\mathrm{Cd}^{2+}$ is different from that of the control, which might be due to $\mathrm{Cd}^{2+}$ inhibiting or promoting the secretion of $\mathrm{Cd}$ resistant microorganism pigments, which may be one of the reasons for its heavy metal resistance [29]. On two mediums, the colony colors of CN35 both changed with the concentration of $\mathrm{Cd}^{2+}$ and the secreted red pigment increased with increases in $\mathrm{Cd}^{2+}$ concentration, which was consistent with the phenomenon that the penicillium with stronger heavy metal resistance could produce more pigments, as has been studied by Sarita Nazareth [28]. The strain in the current research showed stronger resistance, while some pigments could adsorb heavy metals [15] so as to reduce the concentration of effective heavy metals and the toxicity to microorganisms. This might also be one

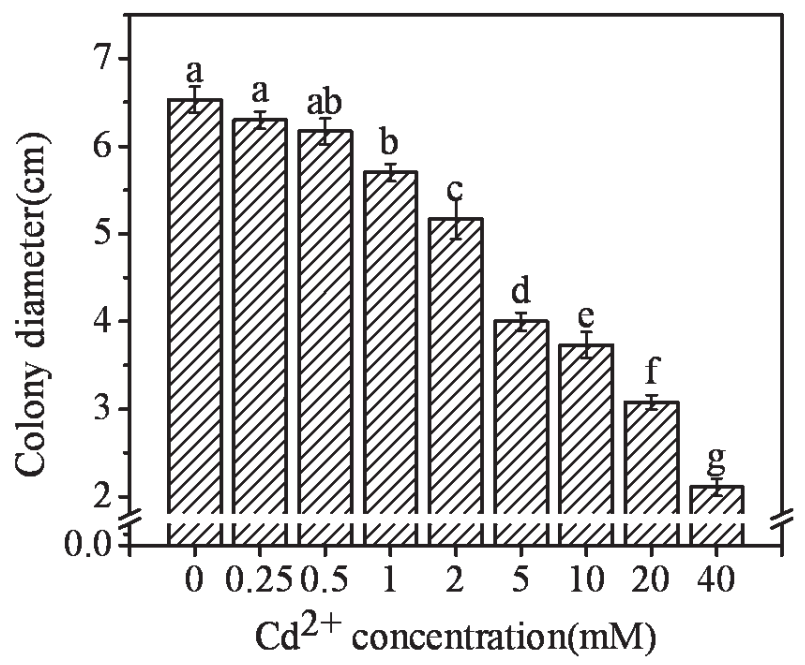

Fig. 7. Effects of $\mathrm{Cd}^{2+}$ concentrations in the culture on growth of CN35 strain. Different letters above the columns indicate significant differences between treatments according to Duncan's multiple range test at $\mathrm{P}<0.05$ level and $\mathrm{n}=3$; vertical bars are standard error of the mean. of the reasons for the high $\mathrm{Cd}$ resistance and adsorption ability of penicillium in the current research. Further study should be done on the ingredients of the red pigment secreted by the strain to explore whether it has the effect of adsorbing heavy metals or changing the biological effectivness of heavy metals. If so, it can be considered as a heavy metal pollution control agent and therefore have far-reaching significance in Cd-polluted microorganism remediation. If it is possible to study the genes responsible for the strain color change with the concentration of heavy metal ions and rebuilding the gene engineering strain, it will be of great significance in the detection of heavy metal pollution where the color changes more sensitively with $\mathrm{Cd}^{2+}$ and the functions are optimized to develop the indicator strain. The fungus can survive in the toxic heavy metal-polluted environment due to its inherent biochemical and structural properties and physiological or genetic adaptation, including morphological change, biological efficacy, and toxicity of heavy metals [15]. When the concentration of $\mathrm{Cd}^{2+}$ reaches a certain value, changes in the morphology of the CN35 colony occur, which may be associated with its heavy metal resistance [30]. The radial growth of the colony is inhibited by heavy metals, most likely because of the toxic heavy metals that accumulate in the hypha or enter into the spores to reduce or inhibit spore germination [31].

\section{Test Result Analysis of the Influence of $\mathrm{pH}$ and Temperature on CN35 Growth and Its Cd Resistance}

Fungal growth is closely related to the acidity and alkalinity of the environment. In a Cd-polluted environment, the $\mathrm{pH}$ value is usually very low. Thus, our study investigates whether the strain has the ability to

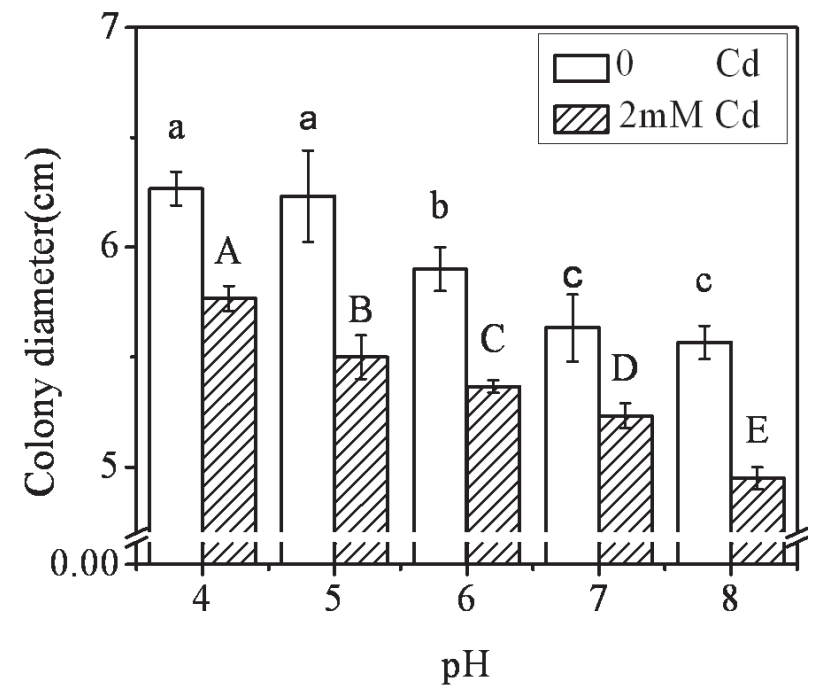

Fig. 8. Influence of $\mathrm{pH}$ ranges on $\mathrm{CN} 35$ growth and $\mathrm{Cd}$ resistance. Different letters (lowercase/uppercase) above the columns indicate significant differences between treatments according to Duncan's multiple range test at $\mathrm{P}<0.05$ level and $\mathrm{n}=3$; vertical bars are standard error of the mean. 


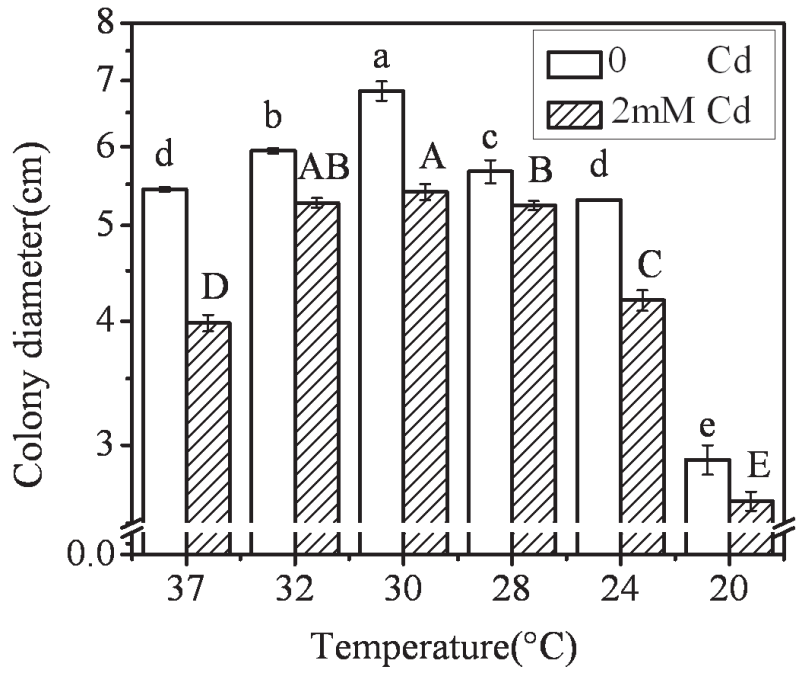

Fig. 9. Influence of different temperatures on CN35 growth and Cd resistance. Different letters (lowercase/uppercase) above the columns indicate significant differences between treatments according to Duncan's multiple range test at $\mathrm{P}<0.05$ level and $\mathrm{n}=3$; vertical bars are standard error of the mean.

adapt to an acidic environment. According to Fig. 8, CN35 could grow well on the PDA mediums without and with $\mathrm{Cd}^{2+}$ (at a concentration of $2 \mathrm{mM}$ ) under the initial $\mathrm{pH}$ value of 4.0 to 8.0 . On the Cd-free medium, when the $\mathrm{pH}$ was 4.5 and 5.0, the diameter of the colony was the largest and vice versa when the $\mathrm{pH}$ was 7.0 and 8.0. Also, significant differences in CN35 growth were observed when $\mathrm{pH}$ was 6.0. These results indicate that it grows better under acidic conditions. The acidity was significantly lower during isolating and screening of Cd-resistant fungus $\mathrm{CN} 35$, indicating that the selection of Cd-resistant fungus was mainly affected by $\mathrm{Cd}^{2+}$ rather than acidity and alkalinity. On the medium with $\mathrm{Cd}$, the colony diameter had a similar relationship with $\mathrm{pH}$ value, indicating that $\mathrm{pH}$ did not affect $\mathrm{Cd}$ resistance ability.

In the growth process of microorganisms, the temperature affects enzyme activities, plasma membrane fluidity, and dissolution of substances, thus resulting in changes in growth rate. From Fig. 9, CN35 could grow under the temperature ranges of $20-37^{\circ} \mathrm{C}$, but it grew slowly at a temperature lower than $20^{\circ} \mathrm{C}$. Without $\mathrm{Cd}$, the best temperature was $30^{\circ} \mathrm{C}$. On the medium with $2 \mathrm{mM} \mathrm{Cd}^{2+}$, it grew best at $30^{\circ} \mathrm{C}$. When there was $\mathrm{Cd}^{2+}$, the colony growth was inhibited, but the growth trends on the mediums with and without $\mathrm{Cd}^{2+}$ were basically similar. This indicates that temperature has a similar influence on strain growth and $\mathrm{Cd}$ resistance.

The temperature and $\mathrm{pH}$ of the environment are two factors that are closely related to the growth of microorganisms. The optimal temperature and $\mathrm{pH}$ for growth can provide a theoretical basis for laboratory cultivation and mass production. An acidic environment is suitable for growth of CN35. When $\mathrm{pH}$ was $4, \mathrm{CN} 35$ shows its growth at its best. At this time, the $\mathrm{pH}$ value was lower than that of the medium when screened with Cd-resistant fungus. This indicates that the selection of a Cd-resistant fungus is mainly affected by $\mathrm{Cd}^{2+}$ rather than acidity and alkalinity. The Cd-polluted soil is usually acidic and a large-scale soil sample measurement has showed that the $\mathrm{pH}$ in Cd-polluted soil is usually between 4.0 and 6.5, and the Cd-tolerant fungus can grow well under acidic conditions. Studies have shown that penicillium is a highly efficient battery of biogeochmecial agents and the soluble, grainy heavy metals in the special environment (such as low $\mathrm{pH}$ value) [32]. Therefore, the characteristic of $\mathrm{CN} 35$ is an advantage for its application in treatment of Cd-polluted paddy field treatment. Paddy soil is exposed in the wild, so its temperature varies greatly with the seasons. $\mathrm{CN} 35$ can grow at $20-37^{\circ} \mathrm{C}$. Its adaptive nature to a wide range of indoor temperatures may contribute to its adaption to paddy fields. In medium containing $\mathrm{Cd}$, the changing trend of colony growth with temperature and $\mathrm{pH}$ is consistent with that in the medium without $\mathrm{Cd}$. These results indicate that $\mathrm{pH}$ does not affect Cd resistance.

\section{Influence of CN35 Strain on Rice Growth} and Its Detoxification on Rice under Cd Stress

No diseases and symptoms were found in the process of rice growth. As shown in Table 1, seeding emergence rates of control without $\mathrm{Cd}$ pollution and the group that

Table 1. Influence of CN35 fermented liquid on the emergence rate, and seedling and root growth of rice under Cd stress.

\begin{tabular}{|c|c|c|c|c|c|c|c|c|}
\hline & \multicolumn{5}{|c|}{$\mathrm{Cd}^{2+}(0)$} & \multicolumn{4}{c|}{$\mathrm{Cd}^{2+}(200 \mathrm{mg} / \mathrm{kg})$} \\
\hline $\begin{array}{c}\text { Fermen- } \\
\text { tation } \\
\text { broth/mL }\end{array}$ & $\begin{array}{c}\text { Mergence } \\
\text { rate/\% }\end{array}$ & $\begin{array}{c}\text { Seedling } \\
\text { length/cm }\end{array}$ & $\begin{array}{c}\text { Seedling fresh } \\
\text { weight/g }\end{array}$ & $\begin{array}{c}\text { Root fresh } \\
\text { weight/g }\end{array}$ & $\begin{array}{c}\text { Mergence } \\
\text { rate/\% }\end{array}$ & $\begin{array}{c}\text { Seedling } \\
\text { length/cm }\end{array}$ & $\begin{array}{c}\text { Seedling fresh } \\
\text { weight/g }\end{array}$ & $\begin{array}{c}\text { Root fresh } \\
\text { weight/g }\end{array}$ \\
\hline 0 & 100 & $20.453 \pm 0.076 \mathrm{a}$ & $0.423 \pm 0.003 \mathrm{c}$ & $0.087 \pm 0.00200 \mathrm{~d}$ & 100 & $15.187 \pm 0.397 \mathrm{c}$ & $0.409 \pm 0.008 \mathrm{c}$ & $0.179 \pm 0.003 \mathrm{~b}$ \\
\hline 20 & 100 & $21.133 \pm 0.479 \mathrm{a}$ & $0.480 \pm 0.010 \mathrm{a}$ & $0.084 \pm 0.00153 \mathrm{~d}$ & 100 & $16.700 \pm 0.020 \mathrm{~b}$ & $0.457 \pm 0.011 \mathrm{~b}$ & $0.196 \pm 0.002 \mathrm{a}$ \\
\hline 40 & 100 & $20.267 \pm 0.223 \mathrm{a}$ & $0.450 \pm 0.012 \mathrm{~b}$ & $0.103 \pm 0.00265 \mathrm{c}$ & 100 & $17.600 \pm 0.040 \mathrm{a}$ & $0.482 \pm 0.005 \mathrm{a}$ & $0.167 \pm 0.007 \mathrm{c}$ \\
\hline 60 & 100 & $19.273 \pm 0.660 \mathrm{~b}$ & $0.452 \pm 0.020 \mathrm{~b}$ & $0.123 \pm 0.00500 \mathrm{~b}$ & N.C. & N.C. & N.C. & N.C. \\
\hline 80 & 100 & $19.347 \pm 0.605 \mathrm{~b}$ & $0.422 \pm 0.002 \mathrm{c}$ & $0.154 \pm 0.00500 \mathrm{a}$ & 100 & $17.613 \pm 0.064 \mathrm{a}$ & $0.490 \pm 0.002 \mathrm{a}$ & $0.154 \pm 0.001 \mathrm{~d}$ \\
\hline
\end{tabular}

*N.C. not conducted 
adds CN35 fermented liquid were both $100 \%$, indicating that $\mathrm{CN} 35$ did not affect the rice seeding emergence rate. When $20 \mathrm{~mL}$ of fermented liquid was added, seedling length increased only slightly. If 20 to $60 \mathrm{~mL}$ of fermented liquid was added, seedling fresh weight increased significantly compared with that of the control. However, if $80 \mathrm{~mL}$ of fermented liquid was added, it showed no significant differences in seedling growth compared with the control. The fresh weight of the root also changed with the adding amount of the fermented liquid. When $20 \mathrm{~mL}$ of fermented liquid was added, root fresh weight showed no significant differences as compared with the control. When 40 to $80 \mathrm{~mL}$ of fermented liquid was added, root fresh weight increased significantly. When $80 \mathrm{~mL}$ of fermented liquid was added, root fresh weight increased by two-fold compared with the control. When $\mathrm{Cd}^{2+}$ was added at a concentration of $200 \mathrm{mg} / \mathrm{kg}$, rice growth was significantly inhibited. However, the addition of fermented liquid changes the growth situation of rice. The addition of 20 to $80 \mathrm{~mL}$ of fermented liquid significantly increased seedling length and root fresh weight. The effect on growth and fresh weight was more apparent when $40 \mathrm{~mL}$ or more fermented liquid was added. However, the fresh weight of the root was increased significantly only when $20 \mathrm{~mL}$ of fermented liquid was added. With the increase of fermented liquid addition, root fresh weight was reduced significantly and became lower than the control. When taken into consideration, the addition of $40 \mathrm{~mL}$ of fermented liquid (per $200 \mathrm{~g}$ soil) was relatively good for both $\mathrm{Cd}$ detoxification and rice growth.

When $60 \mathrm{~mL}$ or more fermented liquid was added, it showed a significant inhibitory role on the growth extension of the rice seedlings. But the fresh weight of both the seeding and root was increased, likely due to the CN35 activities that made the seedlings strong. There were few reports that discussed the effect of penicillium in improving plants growth. For example, Hamayun [33] found that penicillium had a significant role in the growth promotion on Waito-c rice and Crown daisy and secreted nine kinds of gibberellins. The results obtained by Wakelin et al. [34] demonstrated P. radicum as an inoculant that could increase wheat growth rate. We still need to study whether the Cd-resistant fungus can secrete hormones that can promote plant growth in the next stage. When 20 to $80 \mathrm{~mL}$ of fermented liquid was added, both the length and fresh weight of rice seedlings were increased significantly under $\mathrm{Cd}^{2+}$ stress at $200 \mathrm{mg} / \mathrm{kg}$. When more than $20 \mathrm{~mL}$ of fermented liquid was added, root biomass was reduced. This might be because high doses of fermented liquid adsorbed much $\mathrm{Cd}^{2+}$ and reduced $\mathrm{Cd}^{2+}$-induced stress in rice root, so the rice foot fully absorb the nutrient elements in the soil, such as phosphorus [35] and nitrogen [36], and delivered them to the above-ground parts of the rice, making them grow rapidly. The synthesis of a large amount of organic matters increases the fresh weight of rice seedlings and finally improved rice growth. This indicates that CN35 fermented liquid has a detoxification effect on rice under Cd stress. CN35 fermented liquid showed no pathogenicity on rice. A moderate amount of fermented liquid has no inhibitory effect on seedling emergence rate and rice growth and hence meets the basic requirements for its application in Cd-polluted paddy soil remediation. Adding $20 \mathrm{~mL}$ of fermented liquid to every $200 \mathrm{~g}$ of soil has detoxification effects on rice under Cd stress. This in turn provides a theoretical basis for rationally utilizing the Cd-resistant penicillium to treat the Cd-polluted paddy soil and improve the rice growth and safety to use the fungal agent in the polluted soil.

\section{Conclusions}

We screened and isolated a cadmium-resistant strain from the cadmium-polluted paddy soil and established that this strain has Cd adsorption capacity, and then preliminarily identified this functional strain to be Penicillium sp. (named CN35). Furthermore, we also found that $\mathrm{CN} 35$ showed resistance to other common heavy metals such as $\mathrm{Pb}, \mathrm{Zn}$, and $\mathrm{Cu}$. The large-scale culture could be easily achieved, as CN35 could grow fast and well under conditions of a broad temperature $\left(24-37^{\circ} \mathrm{C}\right)$ and $\mathrm{pH}(4-8)$ ranges. The fermentation liquor of CN35 was demonstrated to have no adverse effects on rice seed germination and seedling growth. On the contrary, $40 \mathrm{~mL}$ of the fermented liquor (per $200 \mathrm{~g}$ soil) could improve rice growth, in addition to its good detoxification effect on Cd-stressed rice. Taken together, the Cd-resistant fungus CN35 has potential to be used for treating Cd-polluted rice paddies.

\section{Acknowledgements}

This work was supported by a grant from the State Fiscal Special of China (pilot project of restoration of heavy metal polluted cultivated land and adjustment of crop planting structure of Hunan Province) and the Key Research and Development Program of Hunan (no. 2015NK3053).

\section{References}

1. NORDBERG G.F., NOGAWA K., NORDBERG M. Cadmium-Handbook on the Toxicology of Metals (Fourth Edition)-Chapter 32. Handbook on the Toxicology of Metals, 667, 2015.

2. ANNU GARG A., URMILA. Level of Cd in different types of soil of Rohtak district and its bioremediation. J Environ Chem Eng, 4 (4), 3797, 2016.

3. HOSSAIN Z., HUQ F. Studies on the interaction between $\mathrm{Cd}^{2+}$ ions and DNA. J Inorg Biochem, 90 (3-4), 85, 2002.

4. HORIGUCHI H., TERANISHI H., NIIYA K., AOSHIMA K., KATOH T., SAKURAGAWA N., KASUYA M. Hypoproduction of erythropoietin contributes to anemia in chronic cadmium intoxication: clinical study on Itai-itai disease in Japan. Arch Toxicol, 68 (10), 632, 1994.

5. SUN Y. B., ZHOU Q., X., AN J., LIU W. T., LIU R. Chelator-Enhanced Phytoextraction of Heavy Metals from Contaminated Soil Irrigated by Industrial Wastewater 
with the Hyperaccumulator Plant (Sedum alfredii Hance). Geoderma, 150 (1-2), 106, 2009.

6. JULIN B., WOLK A., JOHANSSON J.E., ANDERSSON S.O. ANDRÉN O., ÅKESSON A. Dietary cadmium exposure and prostate cancer incidence: a population-based prospective cohort study. Brit J Cancer, 107 (5), 895, 2012.

7. ENGSTRÖM A., MICHAËLSSON K., VAHTER M., JULIN B., WOLK A., ÅKESSON A. Associations between dietary cadmium exposure and bone mineral density and risk of osteoporosis and fractures among women. Bone, $\mathbf{5 0}$ (6), 1372, 2012.

8. AKESSON A., JULIN B., WOLK A. Long-term dietary cadmium intake and postmenopausal endometrial cancer incidence: a population-based prospective cohort study. Cancer Res, 68 (15), 6435, 2008.

9. IARC Monographs on the Evaluation of Carcinogenic Risks to Humans, Vol. 57, Occupational exposures of hairdressers and barbers and personal use of hair colourants; some hair dyes, cosmetic colourants, industrial dyestuffs and aromatic amines. Anal Chim Acta, 300 (1), 340, 1995.

10. DENG Z., ZHANG R., SHI Y., HU L., TAN H., CAO L. Characterization of $\mathrm{Cd}-, \mathrm{Pb}-, \mathrm{Zn}$-resistant endophytic Lasiodiplodia $\mathrm{sp}$. MXSF31 from metal accumulating Portulaca oleracea and its potential in promoting the growth of rape in metal-contaminated soils. Environ Sci Pollut R, 21 (3), 2346, 2014

11. ATKINSON B. W., BUX F., KASAN H.C. Considerations for Application of Biosorption Technology to Remediate Metal Contaminated Industrial Effluents. Water Sa, 24 (2), 129, 1998.

12. MARCHAND L., MENCH M., JACOB D.L., OTTE M.L. Metal and metalloid removal in constructed wetlands, with emphasis on the importance of plants and standardized measurements: A review. Environ Pollut, 158 (12), 3447, 2010.

13. XU X., XIA L., ZHU W., ZHANG Z., HUANG Q., CHEN W. Role of Penicillium chrysogenum XJ-1 in the Detoxification and Bioremediation of Cadmium. Front Microbiol, 6, 1422, 2015.

14. ASHIDA J. Adaptation of Fungi to Metal Toxicants. Encyclopaedia Britannica: 4009, 1959.

15. GADD G., M. Interactions of fungip with toxic metals. Springer US, 25, 1994.

16. SIRIPORNADULSIL S., SIRIPORNADULSIL W. Cadmium-tolerant bacteria reduce the uptake of cadmium in rice: Potential for microbial bioremediation. Ecotox Environ Safe, 94, 94, 2013.

17. CHAKRABORTY S., MUKHERJEE A., KHUDABUKHSH A.R., DAS T.K. Cadmium-induced oxidative stress tolerance in cadmium resistant Aspergillus foetidus: its possible role in cadmium bioremediation. Ecotox Environ Safe, 106, 46, 2014.

18. SALINAS E., REZZA I., MARTINEZ L., MS. M.E.D. T., ME. D.O. Removal of cadmium and lead from dilute aqueous solutions by Rhodotorula rubra. Bioresource Technol, 72 (2), $107,2000$.

19. ZOUBOULIS A.I., LOUKIDOU M.X., MATIS K.A. Biosorption of toxic metals from aqueous solutions by bacteria strains isolated from metal-polluted soils. Process Biochem, 39 (8), 909, 2004.

20. ZENG X.X., TANG J.X., YIN H.Q., LIU X.D., PEI J., LIU H.W. Isolation, identification and cadmium adsorption of a high cadmium-resistant Paecilomyces lilacinus. Afr J Biotechnol, 9 (39), 6525, 2010.

21. VISAGIE C.M., HOUBRAKEN J., FRISVAD J.C., HONG S.B., KLAASSEN C.H., PERRONE G., SEIFERT K.A.,
VARGA J., YAGUCHI T., SAMSON R.A. Identification and nomenclature of the genus Penicillium. Stud Mycol, 78, 343, 2014.

22. SCHOCH C.L., SEIFERT K. A., HUHNDORF S., ROBERT V., SPOUGE J.L., LEVESQUE C.A., CHEN W., Fungal Barcoding C. Fungal Barcoding Consortium Author, L., Nuclear ribosomal internal transcribed spacer (ITS) region as a universal DNA barcode marker for Fungi. P Natl Acad Sci Usa, 109 (16), 6241, 2012.

23. GLASS N.L., DONALDSON G.C. Development of primer sets designed for use with the PCR to amplify conserved genes from filamentous ascomycetes. Appl Environ Microb, 61 (4), 1323, 1995.

24. ZENG X.X., CHAI L.Y., TANG J.X., LIU X.D., YANG Z.H. Taxonomy characterization and cadmium biosorption of fungus strain. T Nonferr Metal Soc, 23 (9), 2759, 2013.

25. CHAKRABORTY B.N, SUNAR DEY P. L., CHAKRABORTY B.N, Sunar. RAPD profile and rDNA sequence analysis of Talaromyces flavus and Trichoderma species. Indian J Biotechnol, 10 (4), 487, 2011.

26. DUGAL S., GANGAWANE M. Metal tolerance and potential of penicillium species for use in mycoremediation. J Chem Pharm Res, 4 (5), 2362, 2012.

27. HEMAMBIKA B., JOHNCY M., KANNAN V.R. Biosorption of heavy metals by immobilized and dead fungal cells: A comparative assessment. J Ecol Nat Environ, 3, 2011.

28. NAZARETH S., MARBANIANG T. Effect of heavy metals on cultural and morphological growth characteristics of halotolerant Penicillium morphotypes. J Basic Microb , 48 (5), 363, 2008.

29. LIU A., HUANG W. Separation of tolerant cadmium bacterium strain and its accumulation adsorption of $\mathrm{Cd}^{2+} . \mathrm{J}$ Environ Sci-Chinj, 26 (1), 91, 2006.

30. BAGO B., CHAMBERLAND H., GOULET A., VIERHEILIG H., LAFONTAINE J.G., PICHÉ Y. Effect of Nikkomycin Z, a chitin-synthase inhibitor, on hyphal growth and cell wall structure of two arbuscular-mycorrhizal fungi. Protoplasma, 192 (2), 80, 1996.

31. BABICH H., STOTZKY G., EHRLICH H.L. Environmental Factors that Influence the Toxicity of Heavy Metal and Gaseous Pollutants to Microorganisms. Crit Rev Microbiol, $8(8), 99,2008$.

32. NIU H., XU X.S., WANG J.H., VOLESKY B. Removal of lead from aqueous solutions by Penicillium biomass. Biotechnol Bioeng, 42 (6), 785, 1993.

33. HAMAYUN M., KHAN S.A., IQBAL I., AHMAD B., LEE I.J. Isolation of a gibberellin-producing fungus (Penicillium sp. MH7) and growth promotion of Crown daisy (Chrysanthemum coronarium). J Microbiol Biotech, 20 (1), 202, 2010.

34. WAKELIN S.A., ANSTIS S.T., WARREN R.A., RYDER M.H. The role of pathogen suppression on the growth promotion of wheat by Penicillium radicum. Australas Plant Path, 35 (2), 253, 2006.

35. MALINOWSKI D.P., BELESKY D.P. Neotyphodium coenophialum-endophyte infection affects the ability of tall fescue to use sparingly available phosphorus. J Plant Nutr, 22 (4), 835, 1999.

36. REIS V.M., BALDANI J.I., BALDANI V.L.D., DOBEREINER J. Biological dinitrogen fixation in Gramineae and palm trees. Crit Rev Plant Sci , 19 (3), 227, 2000. 
